DOI: $10.19195 / 0137-1134.107 .5$

\author{
PETRA FERK $K^{*}$
}

Institute for Public-Private Partnership, Slovenia

\title{
PUBLIC SERVICES AS FUNDAMENTAL RIGHTS OF EUROPEAN CITIZENS IN TIMES OF CRISES
}

\section{INTRODUCTION}

In recent years, the EU has faced a number of coinciding crises - food crisis, environmental crisis, economic (financial and debt) crisis, legitimacy crisis, migrant crisis, and disintegration crisis triggered by Brexit, which challenge several fundamental rights and public services, being more exposed and vulnerable in times of crises than in times of good fortune.

This paper aims to demonstrate that in the times of crises the governing structures of the European Union (EU) should be even more aware of the importance of public services in the widest meaning of the word, especially since the "system of public services" as established by the Member States, also guarantees the provision of fundamental rights of European citizens. Therefore, the EU should dedicate more attention to these fundamental rights and commit itself to their provision and implementation. Additionally, since in the last decade the legitimacy of the EU and the European integration has been constantly challenged and since it seems that the EU has failed to properly address the challenges ${ }^{1}$, I argue that public

* Petra Ferk is one of the Founders and a Researcher at the Institute for Public-Private Partnership, Slovenia, as well as Assistant Professor for Public Administration at the Graduate School of Government and European Studies, Slovenia, e-mail: petra.ferk@pppforum.si.

An earlier version of this paper was presented at the International Scientific Conference Citizenship and fundamental rights in the European Union - opportunities and challenges for integration, organised by the Jean Monnet Centre of Excellence, University of Wrocław on 14-15 April 2016. The Conference as well as the special Volume of the Review of Law and Administration of the University of Wrocław dedicated to the 'Protection of fundamental rights in the European Union - opportunities and challenges for integration in times of crises' offered an opportunity to reflect on the role of public services as fundamental rights of the European citizens, for which I am warmly thankful. The comments received from participants at the conference were greatly appreciated.

${ }^{1}$ On the issue of the search for the future dimension of the EU integration see the lecture of G. de Búrca delivered during the Academy of European Law's Summer Course on the Law of the European Union, 2-13 July 2012, published 25 July 2012, available from <https://www.youtube. $\mathrm{com} /$ watch? $\mathrm{v}=\mathrm{j} 9 \mathrm{XHoV} 9--\mathrm{As}>$ (6 August 2016). G. de Búrca explains that if in times of the Schuman 
services should be considered one of the pillars of the future European integration, supporting legitimacy for the mere existence of the EU, just as they represent the legitimacy for the existence of the Member States according to the "traditional theory of public services" established by Duguit.

\section{PUBLIC SERVICES}

\section{PUBLIC SERVICES AS A CONSTITUENT ELEMENT OF THE STATE AND THEIR POSITION IN NATIONAL CONSTITUTIONS}

Contrary to common perception of "public services", at the time of their first identification, they were neither socialist nor interventionist in their nature. The founder of the public services concept in the French legal theory is Léon Duguit, one of the founders of the French administrative law. He was active as a writer in the late 19 th and early 20 th century and was influenced by a sociologist Émile Durkheim, believing that the central society is oriented towards creating "social solidarity" in accordance with the needs of the people and their development ${ }^{2}$.

Duguit states that the term "public service" was created on the day when the differentiation between the rulers and the ruled arose (gouvernants and gouvernés). The reasons for this differentiation were historically conditioned and diverse. He believes that, from the very beginning, the ruled recognised they can impose on the rulers some obligations, while the execution of these obligations is simultaneously the excuse and consequence of their rising power. This should represent the essence of the public service 3 . Duguit's definition of the term "public service" originates from the basic laws of governance, while he tried to answer three specific questions: who are the rulers, what is their obligation and what is the subject of this obligation ${ }^{4}$. He explains that since the civilisation is evolving, the number of activities to be performed by public services - and thus, the number of public services - is increasing as well. The ruled have always demanded the following activities from the rulers: defending the community and its territory against its enemies as well as keeping order in the territory and the community. These activities gave birth to three primary public services: defence, police, and justice. At the beginning of the 20th century, the society already demanded that the State

Declaration (1950) it was clear what "EU" was about and that cooperation had common economic, security and political dimension, today it is less clear and elaborates further on the topic.

2 G. Marcou, "The Role of the State in the Future of Public Services faced with the Problems of Transition and Development: Proposals for a Methodology", [in:] IIAS and the United Nations, Administration and Development: Improving Accountability, Responsiveness and Legal Framework, Amsterdam 1997, p. 18; J.W.F. Allison, A Continental Distinction in the Common Law: A Historical and Comparative Perspective on English Public Law, Oxford 2000, pp. 63-65.

3 L. Duguit, Preobražaji javnog prava, Izdavačka knjižarica Gece Kona, trans. C. Cavaleria, Belgrade 1929, p. 34.

4 Ibid., pp. $42 \mathrm{ff}$. 
intervene in other areas as well: public schools, postal services, railways, electricity, etc. ${ }^{5}$ Today, the variety of these services is even wider.

In the 1930s, Duguit defined a public service as "any activity that has to be governmentally regulated and controlled because it is indispensable to the realisation and development of social solidarity and interdependency [...] so long as it is of such a nature that it cannot be assured save by governmental intervention". He emphasised the importance of a formal criterion regarding the question of which activities are to be organised as public services, and believed that these comprise those activities whose smallest absence leads to disorder in the society ${ }^{6}$.

The special position of public services is also evident from the fact that several public services to be provided by the governing authorities in the Member States are explicitly addressed and their provision guaranteed within the national constitutions of the Member States ${ }^{7}$, although public services as such are not necessarily the constitutional materia ${ }^{8}$.

\section{PUBLIC SERVICES IN THE EU}

The Treaty of Rome (1957), i.e. the Treaty Establishing the European Economic Community (TEEC) ${ }^{9}$, addressed the social policy as inferior in relation to the economic policy, which mostly remained within a national competence ${ }^{10}$. Nevertheless, the Treaty of Rome already introduced a new notion and a fundamental provision of "Services of General Economic Interest" (hereinafter: SGEI) in its Article 90(2) which in the following decades generated numerous debates and developments in the field. The text of the provision in question is almost identical to the current wording of Article 106(2) of the TFEU. When first used, the term SGEI was an entirely new concept that was implemented neither in any language of the Member States nor in the academic literature. In addition, Article 90(2) TEEC represented an exception to the rules of the EEC thereby creating confusion. Nevertheless, the provision has stood the test of time. It remains in the currently applicable TFEU and has even become a driving force for the development of new terms and concepts in the field of public services within EU law ${ }^{11}$.

5 L. Duguit, op. cit., fn. 3, p. 43.

${ }^{6}$ L. Duguit, Law, [in:] the Modern State, trans. F. and H. Laski, New York 1970, p. xiiv.

7 Cf. world's constitutions on-line, available from $<$ https://www.constituteproject.org/> (25 August 2016).

8 See e.g. S. Rodrigues, La nouvelle régulation des services publics en Europe - Énergie, postes, télécommunications et transport, Paris 2000, pp. 51-52, 184.

9 Historical text of the Treaty establishing the European Economic Community (Rome, 1957) is available from $<$ http://eur-lex.europa.eu/legal-content/EN/TXT/?uri=URISERV\%3Axy0023> (25 August 2016).

10 See e.g. M. Acceto et al., "Notranje politike Evropske unije", [in:] K. Vatovec (ed.), Lizbonska pogodba z uvodnimi pojasnili, Ljubljana 2010, p. 127.

${ }^{11}$ See E. Szyszczak, "Why do Public Services Challenge the European Union?”, [in:] E. Szyszczak et al. (eds.), Developments in Services of General Interest, The Hague 2011, pp. 2-3. 
It should be mentioned that in Article 77 the Treaty of Rome utilised another concept to define similar services in the transport regulation section - a concept that was established in the national legal systems of the Member States, i.e. the notion of a "public service". The text of this provision is still in force; namely, the content of current Article 93 TFEU is identical to the corresponding article of TEEC. However, beyond this area, as noted by the Commission, the term is sometimes used ambiguously: it can relate to the fact that a service is offered to the general public and/or in the public interest, or it can be used for the activity of entities in public ownership ${ }^{12}$. To avoid ambiguity, the Commission's documents do not use the term "public service" but follow the terminology which will be introduced infra. It is beneficial to note that in practice as well as in the academic discourse the term "public service" is most often used when referring to all different types of services offered to the general public and/or in the public interest in general. This meaning is also used in this paper.

Insufficient progress in achieving the common market after establishing the EEC led the latter to a more thorough approach in the elimination of trade barriers and the establishment of internal market with the Single European Act (1986). As assessed by Pierre Bauby, the Single European Act did not change anything in the area of public services, yet simultaneously it changed everything ${ }^{13}$. Namely, the Articles related to public services and SGEI remained unchanged, but the objectives of free movement of services have given the European institutions a mandate to establish "the internal market [...] of SGEI", but they lack clearer definitions of the provisions to develop solidarity at the European level. Nevertheless, the consensus limited services of general economic interest to the fields of communications, transport, energy, and critical infrastructure networks required for the realisation of internal market and the free movement of the four freedoms ${ }^{14}$.

The creation of a single internal market coincided with global development: rapid international expansion of the economy and exploitation of the competition's potential, technological advancements, lack of efficiency in certain public services, their complexity, and the growing influence of neoliberal ideologies ${ }^{15}$. In the process of formulating strategies to create an internal market in these areas, the EU gradually began to change national forms of organisation and delivery of public services through the processes of liberalisation, the introduction of competition and market principles, as identified through historical development in each

12 Communication from the Commission, A Quality Framework for Services of General Interest in Europe, $\mathrm{COM(2011)} 900$ final, Brussels, 20.12.2011, p. 4.

13 P. Bauby, "From Rome to Lisbon: SGIs in Primary Law", [in:] E. Szyszczak et al. (eds.), Developments in Services of General Interest, The Hague 2011, p. 24.

14 Ibid., p. 25.

15 Ibid. Also V. Merhar, "Neoklasična ekonomika v funkciji apologije najrazvitejših kapitalističnih držav [Neoclassical Economics in the Function of Apology by the Most Developed Capitalist Countries]", Teorija in praksa 6, 2002, pp. 877-878. 
Member State ${ }^{16}$. Gradually, the fundamental sectors in this area were liberalised: telecommunications, transport, energy, and postal services ${ }^{17}$. Whatever the trends of liberalisation, the EU still holds the belief that some areas cannot (reasonably) be fully liberalised or fully subjected to the rules on the protection of competition. Simultaneously, protection of competition, free movement, and liberalisation also in the field of public services have been perceived by the Member States as "attacks" on the provision of public services, especially SGEI, which indicated the need to recognise the growing importance of public services at the level of the primary sources of the EU. This first occurred in 1997 with the inclusion of new Article 16 in the Treaty of Amsterdam ${ }^{18}$ (now Article 14 TFEU) ${ }^{19}$ and later with the inclusion of SGEI in Article 36 of the EU Charter of Fundamental Rights (2000); and finally, with the introduction of the notion of "services of general interest" (hereinafter: SGIs) and "non-economic services of general interest" (hereinafter: NESGI) in the Protocol No. 26 of the Lisbon Treaty $(2007)^{20}$. Notably, the TFEU also included legislative powers of the European Parliament and of the Council into Article 14 of the TFEU for the adoption of secondary legislation in the form of regulations for SGEIs ${ }^{21}$.

As can be seen from the above information, in the TFEU the notion of "public service" as the broadest conceptual definition in this field can be found only in Article 93 of the TFEU, the concept of "SGI" and "Non-Economic Services of General Interest" (NESGI) can be found in Protocol No. 26 of the TFEU which provides an interpretation of Article 14 of the TFEU and, additionally, the concept of SGEI can be found in Article 106(2) of the TFEU ${ }^{22}$, which is the most discussed provision of them all in terms of dealing with public services within the EU. Until the adoption of the TFEU in 2007, the term SGI was found (only) in the EU practice as an "umbrella concept" to the term "services of general economic interest", as provided today in Article 14 and Article 106(2) TFEU. The concept of SGI includes both commercial and non-commercial services, the provision of

16 P. Bauby, op. cit., fn. 13, p. 25.

17 In detail on the process of liberalisation in specific sectors cf. J.V. Louis, S. Rodrigues, Les services d'intérêt économique général et l'Union européenne, E. Bruylant (ed.), Brussels 2006.

18 See P. Ferk, Gospodarske javne službe na področju transporta [Services of General Economic Interest in the Transport Sector], Ph.D. thesis, Faculty of Law, University of Ljubljana, Ljubljana 2014, p. $223 \mathrm{ff}$.

19 Official Journal of the European Communities, C 340, 10 November 1997, p. 1.

20 See also E. Szyszczak, op. cit., fn. 11, p. 34; M. Krajewski, Grundstrukturen des Rechts öffentlicher Dienstleistungen, Heidelberg 2011, p. xviii.

21 European Commission, Communication from the Commission, Single Market Act Twelve levers to boost growth and strengthen confidence: Working together to create new growth, $\operatorname{COM}(2011) 206$ final, Brussels, 13 April 2011, pp. 17, 18.

22 For additional information on these basic concepts see P. Ferk, "The Influence of the Ongoing Liberalisation of the European Transport Market on the Provision of Public Services and Public Infrastructure", The Journal of Transportation Law, Logistics and Policy 2015, no. 1, pp. 59-100. 
which is defined by the government as being in the public interest, and which are subject to special obligations of public services (PSOs) ${ }^{23}$. Protocol No. 26 of the TFEU clearly divides the SGIs into SGEI and NESGI. From the perspective of EU law, the differentiation into SGEI and NESGI is particularly important on the ground that the TFEU provisions on the protection of competition and especially of prohibition of state aid apply only to SGEI, while NESGI are fully exempted from EU law. Thus, the provisions of the Treaties do not affect at all the competence of the Member States in NESGI.

Having in mind what has been said about the importance of distinguishing between SGEI and NESGI from the viewpoint of EU competition law, I nonetheless decided to use the notion of "public service" as the broadest generic term used in the EU terminology as well as in the legal terminology of the Member States. Namely, this paper does not deal with the competition law perspective on public services and/or specific SGIs/SGEIs where such a consistent division is essential. Rather, the objective of this paper is to present an overview of the trends and challenges of providing public services with an elaboration that public services could be a new foundation for the EU's legitimacy.

\section{FUNDAMENTAL RIGHTS OF THE EUROPEAN CITIZENS}

\section{FUNDAMENTAL RIGHTS AS AN INTEGRAL PART OF NATIONAL CONSTITUTIONS FROM THE EU LAW PERSPECTIVE}

Worldwide as well as within the EU, fundamental rights are a significant and integral part of national constitutions ${ }^{24}$. And it is from the national constitutions that fundamental rights have found their way into the Charter of Fundamental Rights (hereinafter: the Charter) ${ }^{25}$.

As observed by Leonard Besselink, the EU law has had a most ambivalent attitude towards the national constitutions. On the one hand, if a provision of national law stands in the way of the direct effect of EU law, it has to be disregarded by all authorities concerned, whether executive or judicial, central, decentralized, federal or state, regardless of whether it concerns a constitutional provision de-

23 C.H. Bovis, "Financing Services of General Interest in the EU: How do Public Procurement and State Aids Interact to Demarcate between Market Forces and Protection?", European Law Journal 2005, no. 1, p. 81; Communication from the Commission: White Paper on services of general interest, COM/2004/0374 final, Brussels, 12 May 2004, Annex 1, p. 21.

${ }^{24} \mathrm{Cf}$. world's consitutions on-line available from $<$ https://www.constituteproject.org/> $(25 \mathrm{Au}-$ gust 2016). See also T. Ginsburg, R. Dixon (ed.), Comparative Constitutional Law, Edward Elgar Cheltenham, UK 2011; A. Rainer (ed.), The Convergence of the Fundamental Rights Protection in Europe, Springer, Dordrecht 2016.

${ }^{25}$ Under the influence of Germany. To the issue see L.F.M. Besselink, "The Member States, the National Constitutions and the Scope of the Charter", Maastricht Journal 2001, no. 1, p. 68. 
aling with fundamental human rights, constitutional provisions of an institutional nature, provisions of acts of parliament or of any other status ${ }^{26}$. On the other hand, the national constitutions - in so far as they constitute a "constitutional tradition common to the Member States" - act as a source of inspiration for the CJEU when providing fundamental rights protection. As additionally observed by Besselink, clearly, this was by way of mitigating the consequences to which strict application of the Simmenthal ${ }^{27}$ principle might lead ${ }^{28}$. From this perspective, it seems logical that several traces of the national constitutional traditions can be found in the Charter ${ }^{29}$.

\section{THE EU CHARTER OF FUNDAMENTAL RIGHTS}

The European Council at the Cologne summit in 1999 stated that "there appears to be a need, at the present stage of the Union's development, to establish a Charter of fundamental rights in order to make their overriding importance and relevance more visible to the Union's citizens". The Charter was to include the general rights of liberty and equality as well as fundamental rights that pertain only to the Union's citizens and additionally it had to take account also of economic and social rights. The European Parliament which had been calling for such a charter for many years, warmly welcomed the decision ${ }^{30}$. The Charter of Fundamental Rights of the European Union was solemnly proclaimed by the Parliament, the Council and the Commission in Nice in 2000. After being amended, it was proclaimed again in 2007. However, the Charter became legally binding only on 1 December 2009 , when the Treaty of Lisbon entered into force, thereby permanently filling the perceived statutory human rights gap in EU law.

Article 6(1) of the Treaty on European Union (TEU) ${ }^{31}$ now provides that the Union recognises the rights, freedoms, and principles set out in the Charter and that the provisions of the Charter shall have the same legal value as the Treaties ${ }^{32}$. Due to Article 6(1), the Charter has the same legal status in EU law as the provisions of the EU Treaties themselves. Furthermore, Article 6(2) provides that the European Union shall accede to the Convention for the Protection of Human Rights and Fundamental Freedoms (ECHR). Deriving from Article 6(3) which provides that "Fundamental rights, as guaranteed by the European Convention for the Pro-

26 Ibid.

27 Case 106/77, Simmenthal ECLI:EU:C:1978:49.

28 L.F.M. Besselink, op. cit., fn. 25, pp. 68-69.

${ }^{29}$ For assessment see ibid.

30 See $<$ http://www.europarl.europa.eu/charter/press/index_en.htm $>$ (accessed 14 August 2016).

31 OJ C 326, 26 October 2012, pp. 13-390.

32 V. Trstenjak, E. Beysen, "The Growing Overlap of Fundamental Freedoms and Fundamental Rights in the Case-law of the CJEU", European Law Review 2013, no. 38/3, p. 293. 
tection of Human Rights and Fundamental Freedoms and as they result from the constitutional traditions common to the Member States, shall constitute general principles of the Union's law", the EU now features three types of human rights catalogues: the Charter, the ECHR, and the national constitutions of the Member States. As observed by Arnold Rainer and Eva Feldbaum, all three protection levels are autonomous, yet functionally interconnected; a process of convergence is taking place in the field of fundamental rights in Europe ${ }^{33}$. Additionally, due attention should be paid to the international legal framework, such as the United Nations treaties and conventions to which the Member States and/or the EU are parties $^{34}$. If a state is a party to an international human rights instrument, it has an obligation to ensure observance of the provisions the treaty contains. International legal instruments can offer the legal basis needed to propose a fundamental rights initiative ${ }^{35}$. Nonetheless, this paper primarily deals with the Charter.

The provisions of the Charter address the institutions and bodies of the Union with due regard to the principle of subsidiarity and to the Member States only when they are implementing the Union law (rationae personae) ${ }^{36}$. The Charter contains rights and freedoms under six titles: Dignity, Freedoms, Equality, Solidarity, Citizens' Rights, and Justice (ratione materiae). Title VII contains general provisions. While the rights provided to "everyone" are addressed in titles I-IV and title VI, title V provides the Citizens' Rights. The substantive provisions of Articles 1-50 of the Charter should be read together with the general provisions of Articles 51-54 of the Charter, with accompanying explanations ${ }^{37}$.

\section{ARE PUBLIC SERVICES AND FUNDAMENTAL RIGHTS REALLY TWO DIFFERENT WORLDS, OR ARE THEY JUST TWO SIDES OF THE SAME COIN?}

Both institutions - the institution of fundamental rights and the institution of public services - coexist in all three catalogues of fundamental rights, at least

33 A. Rainer, E. Feldbaum, "Aspects of Fundamental Rights Convergence in Europe with Some Comparative References to the Developments in Germany, United Kingdom and France", [in:] A. Rainer (ed.), op. cit., fn. 24, p. 1 ff.

34 For the first time in history, the EU has become a party to an international human rights treaty through becoming a party to the United Nation's (UN) Convention on the Rights of People with Disabilities. See Commission's Press Release, IP/11/4 (3 January 2011).

35 EU and International law, European Union Agency for Fundamental Rights. Available from <http://fra.europa.eu/en/joinedup/tools/understanding-fundamental-rights/respecting-legalframeworks/eu-and-international> (15 August 2016).

36 Article 51(1) of the Charter.

37 Article 6(1) of the TEU. On this issue see D. Denman, "The Charter of Fundamental Rights", European Human Rights Law Review 2010, no. 4, pp. 349-359. 
on the level of individual fundamental rights, being guaranteed and realised to a large extent through the "system" of public services ${ }^{38}$.

As can be derived from the Charter, European citizen's rights cover a broad spectrum of rights, among which a significant number of the rights of European citizens are assured by the Member States predominantely in the form of public services, e.g. the right to education (Article 14), guaranteeing the rights of the children (Article 24) and the rights of the elderly (Article 25), legal, economic and social protection of families (Article 33), social security and social assistance (Article 34), health care (Article 35), and environmental protection (Article 37).

If it were held that the identified rights of EU citizens are provided through the "system" of public services in the Member States, then vice versa, it can also be held, that a significant number of public services (of non-economic and economic nature) are being either guaranteed or recognised to the EU citizens by the Charter. If the above identified rights are in nature predominantly "non-economic services of general interest" and "social services of general interest", separate Article 36 of the Charter recognises the right to access to the "services of general economic interest as provided for in national laws and practices" 39 : "The Union recognises and respects access to services of general economic interest as provided for in national laws and practices, in accordance with the Treaty establishing the European Community, in order to promote the social and territorial cohesion of the Union".

This article is fully consistent with Article 14 of the TFEU and does not create any new rights. It simply sets out the principle of respect by the Union for the access to services of general economic interest as provided by national provisions when those provisions are compatible with the Union law ${ }^{40}$. Notably, in the Charter, the SGEIs are presented under the heading of solidarity, and not that of citizenship ${ }^{41}$. Nevertheless, individual "non-economic services of general interest" as well as

38 Cf. world's constitutions on-line available from <https://www.constituteproject.org/> (25 August 2016). On socio-economic rights, which seem to be predominant in this field, see D.M. Davies, "Socio-economic Rights: Has the Promise of Eradicating the Divide between First and Second Generation Rights Been Fulfilled?", [in:] T. Ginsburg, R. Dixon (ed.), op. cit., fn. 24, p. 519. See also C. Fabre, who argues for the constitutionalising of the social rights - C. Fabre, "Constitutionalising Social Rights", The Journal of Political Philosophy 1998, no. 3, pp. 263-284; C. Fabre, Social Rights Under the Constitution - Government and the Decent Life, Oxford 2000.

39 See J. Zemanek, "Access to the Service of General Economic Interest under Article 36 of the Charter of Fundamental Rights EU and the National Law", [in:] A. Rainer (ed.), op. cit., fn. 24.

${ }^{40}$ Explanations relating to the Charter of Fundamental Rights, OJ C 303, 14 December 2007, p. 17. The explanations were originally prepared under the authority of the Praesidium of the Convention which drafted the Charter of Fundamental Rights of the European Union. Although they do not as such have the status of law, they are a valuable tool for interpretation intended to clarify the provisions of the Charter. See European Union Agency for Fundamental Rights (FRA), <http:// fra.europa.eu/en/charterpedia/article/36-access-services-general-economic-interest\#group-info-caselaws> (15 August 2016).

41 W. Sauter, Public Services in EU Law, Cambridge 2014, p. 229. 
"services of general economic interest" are protected and guaranteed to the EU citizens by the Charter.

As observed by Gráinne de Búrca, after the Charter gained its binding force, the role of the CJEU as a human rights adjudicator has grown, not only due to the function of the coming into the force of the Charter, but also as a consequence of the continued expansion of the scope of EU law and policy. Namely, a significant part of EU's legislative corpus now covers areas such as immigration and asylum, security and privacy, alongside the more traditional fields of the EU policy, including competition and market regulation, demonstrating that the EU is, despite its recent economic woes, a powerful and pervasive law-making entity with the capacity to impinge on fields of human freedom and welfare in many respects ${ }^{42}$.

However, public services as such, leaving the discussion of the scope of those services on the side, are not considered to act in the function of the fundamental rights of the EU citizens. Nonetheless, the significance of citizenship to the topic of public services is indisputable ${ }^{43}$. Namely, the Court has enforced access to certain public services, in particular social services, on the grounds of citizenship ${ }^{44}$. It must be noted, however, as observed by Wolf Sauter, that this does not mean the CJEU case law is grounded in the special status of public services. Rather the reverse is true: because free movement and/or citizenship are involved, a right accrues that is not much more - but also no less - than a very broad entitlement to non-discrimination ${ }^{45}$.

And yet, in times of the EU's legitimacy crisis, public services could represent the key for the future European integration and a constituent pillar of the EU's legitimacy.

It must be noted that such belief is largely present in the civil society and backed by the trade unions; e.g. the European Trade Union Confederation (ETUC) regards the universal access to public services to be a fundamental right and a pillar of European Social Model ${ }^{46}$. Although in principle I agree with such a position, I do not share the view largely present in the society (and the trade unions) that those services should be provided predominantely with public resources, since I believe that such position is not financially sustainable in given economic circumstances and relatively high standard of public services that exist in Europe.

42 G. de Búrca, "After the EU Charter of Fundamental Rights: The Court of Justice as a Human Rights Adjudicator?”, Maastricht Journal 2013, no. 2, p. 169.

43 W. Sauter, op. cit., fn. 41, p. 105.

44 W. Sauter, op. cit., fn. 41, p. 81. Reference to Case C-184/99, Rudy Grzelczykv Centre public d'aide sociale d'Ottignies-Louvain-la-Neuve [2001] ECR I-06193.

45 W. Sauter, op. cit., fn. 41, pp. 103-104.

46 See European Trade Union Confederation. Public Services, March 2015, available from $<$ https://www.etuc.org/public-services-services-general-economic-interest-sgeis $>$ (15 August 2016). 


\section{PUBLIC SERVICES AS FUNDAMENTAL RIGHTS BETWEEN A ROCK AND A HARD PLACE}

The provision of public services and public infrastructure by the Member States is in the times of crises and ongoing liberalisation in unenviable position. Namely, various crises that have been affecting Europe in the last decade have forced many European countries to seek financial assistance from international institutions, such as the European Commission, the European Central Bank or the International Monetary Fund (the Troika). These institutions have imposed a series of austerity measures that the countries assisted had to (and still must) implement, many of which are directed at the reduction of public expenditure. Civil society organisations warn that fundamental rights are endangered by the destruction of public services ${ }^{47}$, while studies have confirmed that the financial and economic crises and austerity measures imposed in response thereto have doubtlessly influenced fundamental rights of individuals. To name but a few: education, healthcare, work, pension, access to justice, as well as freedom of expression and assembly, right to housing, right to property, labour rights, right to social security ${ }^{48}$. Therefore, the general perception is present that the Member States are struggling alone for the provision of public services and public infrastructure, although, for several years now, the EU has been striving to set a global role model of a social society founded on the concepts of equal treatment, solidarity, cohesion, and respect of public interest.

The EU is searching for the solution to the economic crisis in the further opening of the markets which requires further liberalisation. Consequently, the development of public services in the EU is oriented towards further liberalisation, in addition to "traditionally" present liberalisation trend in the EU as the antipode to the (national) concept of public services which is withdrawing steadily ${ }^{49}$.

Therefore, it is not surprising that the Member States, civil society, and trade unions feel that it is becoming ever more difficult to provide public services and public infrastructure and that they protect the public services and that resistance

47 Magistrats européens pour la démocratie et les libertés, Fundamental rights are put in question by the destruction of Public Services, 13 November 2012, available from $<\mathrm{http} / / \mathrm{www}$.medelnet. eu/index.php?option $=$ com_content\&view $=$ article $\&$ id $=190 \% 3$ Astrike-on-nov- 14 th $\&$ catid $=48 \% 3$ Aladefense-des-droits-economiques-et-sociaux\&Itemid=58\&lang=en $>$ (15 August 2016).

48 See A. Ivanković Tamamović, The impact of the crisis on fundamental rights across Member States of the EU, comparative analysis, Study for European Parliament, LIBE Committee, 2015, available from <http://www.europarl.europa.eu/RegData/etudes/STUD/2015/510021/ IPOL_STU(2015)510021_EN.pdf> (15 August 2016); FRA working paper, Protecting fundamental rights during the economic crisis, 2010, available from <http://fra.europa.eu/sites/default/files/ fra_uploads/1423-FRA-Working-paper-FR-during-crisis-Dec10_EN.pdf $>$ (14 August 2016).

49 See P. Ferk, "The Influence of the Ongoing Liberalisation of the European Transport Market on the Provision of Public Services and Public Infrastructure", The Journal of Transportation Law, Logistics and Policy 2015, no. 1/2, p. 95. 
towards further liberalisation is present. Alongside the crises, further liberalisation of the market is seen as an additional threat to public services and danger for the European social model; thus keeping public services out of potential trade pacts has become the number one priority for the unions across Europe ${ }^{50}$. The crisis of public services, or even the destruction of public services as noted by some civil society organisations $^{51}$, is seen as threatening the existence of fundamental rights. Even the United Nations Human Rights Commissioner, among others, has identified the liberalisation of services as a threat to the achievement of certain human rights, due to the constraints it arguably places on government's regulatory autonomy ${ }^{52}$.

Meanwhile, the EU does not offer any alternatives to be able to reject the concerns that provision of public services and public infrastructure is being jeopardised by liberalisation and the crises. A pronounced deficiency of a single and coherent common vision of public services is present at the EU level, and the current situation of providing public services in the EU is fragmented, i.e. each Member State protects its individual interests and struggles with the provision of public services and public infrastructure. The fact that a number of questions of public services have exceeded the frames of individual countries has been neglected ${ }^{53}$.

However, at the declaratory level the EU is striving to set a global model for a social society founded on the concepts of equal treatment, solidarity, cohesion, and respect of public interest. In light of these efforts, one should note the recent action of the Commission to the President of the European Commission to establish the "European Pillar of Social Rights". Jean-Claude Juncker observed in 2015 that "our European Union is not in a good state. There is not enough Europe in this Union. And there is not enough Union in this Union. We have to change this. And we have to change this now" 54 . Namely, despite the fact that Europe has managed to restore economic growth, it still tackles the consequences of the financial and debt crisis: poverty, social exclusion, inequality, and high unemployment rates. Simultaneously, the challenges of the 21st century have to be addressed. Therefore, in March 2016, the European Commission presented the first, preliminary outline

50 Education International, European unions: Education is a public good, not a commodity (15 January 2015), available from <http://www.ei-ie.org/en/news/news_details/3395> (15 August 2016).

51 Magistrats européens pour la démocratie et les libertés, op. cit., fn. 47.

52 Economic and Social Commission on Human Rights: Liberalisation of Trade in Services and Human Rights: Report of the High Commissioner (25 June 2002) (E/CN.4/Sub.2/2002/9), Economic and Social Council, pp. 3-4. On this issue see also K. Connolly, "Finding Space for Regulatory Autonomy in GATS Article XVII after EC - Seals: Public Services and the 'Likeness' of Public and Private Service Providers", Legal Issues of Economic Integration 2015, no. 42/1, pp. 57-83.

53 For further elaboration see P. Ferk, fn.47, p. 95.

54 J.C. Juncker, State of the Union 2015: Time for Honesty, Unity and Solidarity (9 September 2015), European Commission Press release, available from <http://europa.eu/rapid/press-release SPEECH-15-5614_en.htm> (17 August 2016). 
of what should become the "European Pillar of Social Rights"55 and launched a public consultation on the European Pillar of Social Rights ${ }^{56}$. The outcome of the debate should feed into a final text of the European Pillar of Social Rights. The Pillar should build on, and complement, the EU social acquis in order to guide policies in a number of fields essential for well-functioning and fair labour markets and welfare systems. The proposed principles are not meant to replace existing rights, but to offer a way to assess and, in the future, approximate the performances of national employment and social policies. For the purpose of structuring the consultation, the preliminary outline of the European Pillar of Social Rights is divided into three main categories in the field of employment and social policies. These are: first, equal opportunities and access to the labour market, which includes skills development, life-long learning and active support for employment; second, fair working conditions need to be established an adequate and reliable balance of rights and obligations between workers and employers; third, adequate and sustainable social protection which includes access to health, social protection benefits and high quality services, including childcare, healthcare and long-term care which are essential to ensure a dignified living and protection against life's risks ${ }^{57}$. Noticeably, the initiative addresses only public services of a social nature. However, although the initiative addresses social services - which can be of an economic or non-economic nature, but mostly fall within the category of non-economic, i.e. NESGIs - and neglects SGEIs, it nonetheless demonstrates the willingness of the Commission towards the change in this field.

Clearly, on the one hand the EU struggles to create an "ideal" European common market that accommodates the basic principles of free movement, market economy, dynamism, full respect of the principle of competition, and general prohibition of state aid. On the other hand, there are values of the European Social Model. Behind the so frequently pronounced "European Social Model" there is a simple, centuries old aspiration for a social and rightful society that respects the public interest. In comparison, the European common market represents a more recent ambition. These, sometimes diametrically opposed, fundamental values advocated by the EU appear to be unexpectedly incompatible, but still represent an unavoidable consequence of the EU development ${ }^{58}$. It is true that the incompatibility has always been present — from the very beginning of the European

55 J.C. Juncker, Towards a European Pillar of Social Rights (9 September 2015), available from $<$ http://ec.europa.eu/priorities/deeper-and-fairer-economic-and-monetary-union/towards-europeanpillar-social-rights_en> (17 August 2016).

56 Commission launches a public consultation on the European Pillar of Social Rights (8 March 2016), European Commission Press release. Available at $<$ http://europa.eu/rapid/press-release_IP16-544_en.htm> (on 17 August 2016).

57 J.C. Juncker, Towards a European ..., fn. 55.

58 P. Ferk, Gospodarske javne službe [Services of General Economic Interest], Master Thesis 2008, Faculty of Law, University of Ljubljana, pp. 8-9. 
integration, however, the crises, and recently the Brexit indicating the possibilities of further disintegration, have made this opposition more notable. It is evident that some action is needed. Until now it has always seemed that free trade was considered more important than public services and that the market would properly address the open issues and provide those services. However, I believe that if we expect the market liberalisation to resolve the open issues by its mere existence, we might be proven wrong ${ }^{59}$. The model might work in times of good fortune, but can easily fail in severe times. Therefore, the aspiration for a social and rightful society that actively guarantees the fundamental rights traditionally inherent for the Europeans is not surprising. The EU citizens feel they are not adequately reciprocated for the significant part of the relinquished sovereignty, i.e. they are not getting back "the things that matter". At the time of establishing the EU, the picture of what the EU was there for might have been clearer. However, now the picture is blurred. The EU citizens certainly have not joined the club to gain e.g. the classification standards for bananas, which are often perceived as a flagship of the needless European bureaucracy. The democratic deficit is obvious. I believe it is wrongly considered that this deficit might be filled by adjusting the rules on the EU governing structures to make them more accountable. In my view, the democratic deficit can be addressed only if the $\mathrm{EU}$ is able to demonstrate to its citizens that it "cares" for their everyday needs, for the need to feel secure, and guarantee human rights on a higher level than the Member States themselves. This is why the EU citizens were willing to relinquish a part of their sovereignty and this is the issue that the EU should start to actively address.

\section{THE WAY FORWARD}

As observed by Albert Sanchez-Graells and Erika Szyszczak "the competence of the Member States to develop national public services is curtailed by the operation of EU economic law, which may restrict and may inhibit the necessary degree of diversity and experimentalism needed to modernise and provide efficient public services in the EU" 60 . Therefore, in my view, the EU should put more effort into the provision of public services, including services such as defence, police and justice which were identified as "fundamental" by the classic theory of public services and have turned out to be one of key weak points of the EU rather than just

59 P. Ferk, op. cit., fn. 49, p. 95.

60 A. Sanchez-Graells, E. Szyszczak, Modernising Social Services in the Single Market: Putting the Market into the Social (September 15, 2013). Accepted for presentation at the "Fostering Growth: Reinforcing the Internal Market" conference, organised by CEU San Pablo in Madrid, Spain on the 28-29 October 2013, p. 2. Available from SSRN <http://ssrn.com/abstract=2326157> (27 August 2016). 
economic integration, since the invested efforts of the EU until now seem to have failed to bring the desired results. This might enable a higher level of integration at the moment seems as the only alternative to the "disorderly disintegration, that will leave Europe worse off than where it would have been had the EU not been brought into existence", as observed by George Soros ${ }^{61}$.

As seen from the above both the individual Member States as well as the Commission are working towards the direction of Europe to become a socially oriented society. Nevertheless, the general perception present in the society is that public services, fundamental rights, and modern welfare state are endangered. In its recent action, the establishment of the European Pillar of Social Rights, as presented above, the EU pursues the development of a social and cohesive model of society. However, it still seems that these actions fail to change the perspective of the EU citizens and that the EU only advocates the solidarity model on the nominal level, while the citizens and the Member States feel that it is becoming more difficult to adequately provide public services.

Here, I try to identify the possible steps which might enable public services - of a social and non-social nature, and of an economic and non-economic nature - to become one of the pillars of the future European integration.

First, the EU should decidedly revert to the position in Communication on SGI of 1996, when SGIs were recognised as a key element in the European model of society, and when it was stated:

European societies are committed to the general interest services they have created which meet basic needs. These services play an important role as social cement over and above simple practical considerations. They also have a symbolic value, reflecting a sense of community that people can identify with. They form part of the cultural identity of everyday life in all European countries. [...] General interest services are meant to serve a society as a whole and therefore all those living in it. The same applies in the Community to the universal service concept ${ }^{62}$.

Then, as assessed by Caroline Wehlander ${ }^{63}$, the Commission seemed to be more inspired by Durkheim's theories, explicitly connecting SGIs to their importance for social cohesion, and — in a more diffuse way — by Duguit's idea that securing certain services indispensable for social cohesion requires state intervention, "serving the public" being the very fundament of the state legitimacy. However, this French public services' sociological and legal heritage still influential

61 G. Soros, Brexit and the Future of Europe (25 June 2016), Project Syndicate. Available from $<$ https://www.project-syndicate.org/commentary/brexit-eu-disintegration-inevitable-by-georgesoros-2016-06> (17 August 2016).

${ }^{62}$ Communication from the Commission, Services of general interest in Europe, 1996 OJ C281/03. p. 4 ff, emphasis added.

63 C. Wehlander, Services of General Economic Interest as a Constitutional Concept of EU Law, The Hague 2016, pp. 86-87. 
in 1996 under the Delors Commission was toned down in 2007 by the Barroso Commission $^{64}$ :

These services are essential for the daily life of citizens and enterprises, and reflect Europe's model of society. They play a major role in ensuring social, economic and territorial cohesion throughout the Union and are vital for the sustainable development of the EU in terms of higher levels of employment, social inclusion, economic growth and environmental quality.

Consequently, the rhetoric used in official documents should change, giving signals to the EU citizens that the EU "cares". Namely, drawing from the Continental Europe's sociological and legal heritage, it is hard to imagine that the EU citizens would support a higher level of integration of the EU, without that sociological and legal heritage being admitted. However, changes are required in order for Europe be able to keep what characteristically defines the European society.

Here, additionally, a closer look should be taken at the trend of liberalisation in the field of provision of public services and public infrastructure. Namely, in my view, one of the reasons for a general perception in the society that public services are endangered can be found in the development of the liberalisation and privatisation $^{65}$. From the viewpoint of the provision of public services, liberalisation is not necessarily damaging, as it is often considered and presented by the civil society and the unions. However, liberalisation in the field of public services should be more in correlation with "contracting-out" and more importantly, presented to the general public, including civil societies and trade unions, as necessary tools for attracting the private investments for the provision of public services and public infrastructure, whereas the provision of public services and public infrastructure remains public responsibility and under a required level of public control. We have to be aware that the position of the civil society for the provision of public services in public domain is financially unsustainable in the long run, and cannot be supported uncritically. Namely, standards are high and public funds are limited. Therefore it seems wise to include private funds into financing of the provision of public services and public infrastructure in the form of public-private partnerships.

Second, it would be sensible for the EU to consider adopting the idea of providing a set of essential public services to all EU citizens as one of its fundamental missions. Additionally, if the EU aims to follow the social and the cohesion model

${ }^{64}$ Communication from the Commission, Services of general interest, including social services of general interest: A new European commitment, COM(2007) 724 final, p. 3, emphasis added.

65 On the basic characteristics of the distinction see e.g. M. Pečarič, B. Bugarič, Javne službe [Public Services], Fakulteta za Upravo, Univerza v Ljubljani, Ljubljana 2011, pp. 207-230; J.A. Kay, D.J. Thompson, Privatisation: A Policy in Search of a Rationale, "The Economic Journal" 96, 1986, no. 381, pp. 18-32; J. Vickers, G. Yarrow, "Economic Perspectives on Privatization", The Journal of Economic Perspectives 5, 1991, no. 2, pp. 111-132. 
of society, perhaps even a consensus could be reached on the minimum standard of the "welfare Union" 66 . The EU should identify the basic public services (of a social and non-social nature) that are essential to all EU citizens in all Member States. And although this might not seem very realistic in the given circumstances, maybe even the "fundamental public services" or/and "fundamental universal service (obligation)" concept could be identified. The EU should start to ponder on the matter of the minimal consensus on what the declared social and solidarity oriented EU means in the real world, not only at abstract level. Complementarily, appropriate organisational, financial and legal mechanisms/models should be identified and presented, enabling the provision of those services, as indicated in the first action of this section.

Third, it will be quite difficult to achieve the above objectives until it remains unclear which services are being discussed when we are referring to SGI, NESGI or SGEI, as they are not clearly defined. Namely, regardless of the importance of the distinction between SGEI and NESGI at the EU level from the viewpoint of competition law, there is still no clear definition of the key notions. Numerous authors are asking the question why a definition of the term SGEI does not exist at the EU level, and whether it is appropriate. Sauter lists two possible reasons. The first logical argument he provides is that the TFEU offers the Member States a wide discretion to define the mission of SGEIs and the organizational structure to deliver them. He supports and explains this argument by stating that none of the many drafts amending the provision contained a proposal for the definition of the term. The second probable cause for the lack of any SGEI list according to Sauter resides in the dynamic nature of SGEIs: the perception of what this concept includes is dependent on the time and place of such discussion ${ }^{67}$. The scope of services that can be performed on a given market is subject to technological, economic and social changes, and it evolves over time ${ }^{68}$. Consequently, the distinction between economic and non-economic activities is dynamic and changing. For example, in recent decades an increasing number of activities have become economically important, while in many cases this distinction have become blurred. Thus, it is

66 See T. Boeri, Why We Need a Welfare Union in Europe (23 February 2015), Social Europe. Available at <https://www.socialeurope.eu/2015/02/welfare-union/> (17 August 2016).

67 See W. Sauter, "Services of General Economic Interest and Universal Service in EU Law", European Law Review 2008, no. 33(2), pp. 293-315.

68 E.g. Rottmann notes about signs of the Commission's resignation in its efforts to implement the so-called European definition. Rottmann's main findings are summarised in: A. Ferčič, "Službe in storitve splošnega gospodarskega pomena: terminološke dileme in problem definicije", Podjetje in delo 36, 2010, no. 3/4, p. 558, fn. 100. M. Rottmann, Vom Wettbewerbsrecht zur Ordnungspolitik: Art. 86 Abs. 2 EGV, Schriftenreihe Europäisches Recht, Politik und Wirtschaft, Baden-Baden 2008, p. 230. In this work, Rottmann (pp. 177-229) also tries to form a substantive and an empirical definition of SGEIs, reaching the conclusion that neither of these definitions is possible. 
neither feasible nor desirable to identify a definitive a priori list of all SGEIs which should be considered as non-commercial services ${ }^{69}$.

There is a huge gap in the understanding of public services at the EU level from the viewpoint of the Member States. Reading primary EU law sources, everything looks fine and the concepts of SGI, NESGI or SGEI appear to be clear. However, when trying to categorise a specific public service in an individual Member State, the situation is different. The notions are too abstract and the CJEU's and the Commission's casuistic approach fails to offer a structured clarification. Consequently, civil servants in the Member States struggle to ensure that they have not committed a "manifest error" when assuring the provision of a specific SGEI. The rules which have to be considered in order to properly provide and design the economic structure of financing public services and public infrastructure are expanding. The financial and legal assessments behind the provision of public services are becoming more complex; yet, they still fail to assure with certainty that a "manifest error" 70 will not occur, since the casuistic approach is present in evaluations of the measures by the Commission and the CJEU. Despite the extensive sectorial legislation, the line between the economic and non-economic nature of activities became blurred ${ }^{71}$. A clear need is recognised, these institutions ought to be systematically clarified ${ }^{72}$.

Originally, we all raised hopes that such an analytical and/or instructional assessment would be conducted by the Commission, and even at a later stage adopted as a legislative measure, since Article 14 TFEU included legislative powers by the European Parliament and of the Council for the adoption of secondary legislation in the form of regulations for SGEIs. However, the Commission did not decide to use this possibility. The Commission's decision not to use the legislative initiative — although it could - seems sensible from the Commission's perspective. Even before the TFEU entered into force, the Commission has stated that it would not

69 European Commission, Commission Green Paper on services of general interest, $\mathrm{COM}(2003)$ 270 final, 21 May 2003, Brussels, pp. 14-15. Green Paper 2003, pp. 14-15; On the dynamic nature of SGEIs see also J.L. Buendia Sierra, Exclusive Rights and State Monopolies under EC Law: Article 86 (former Article 90) of the EC Treaty, Oxford 1999, pp. 283-284. The General Court also pointed out the dynamic nature of SGEIs in Case T-289/03, BUPA and Others $v$ Commission [2008] ECR II-00081, para. 164. On analysis of the $B U P A$ judgement and further references see P. Ferk, op. cit., fn. 18, pp. 350-356. See also C-113/13, Azienda sanitaria locale n. 5 »Spezzino « and Others $v$ San Lorenzo Soc. coop. sociale and Croce Verde Cogema cooperativa sociale Onlus, not yet published in Reports of Cases. On the analysis of - for this paper — relevant issues of the Spezzino Judgement see R. Caranta, "After Spezzino (Case-C-113/13): A Major Loophole Allowing Direct Awards in the Social Sector", EPPPL 2016, no. 1, p. 14-21; A. Sánchez-Graells, "Competition and State Aid Implications of the Spezzino Judgment (C-113/13): the Scope for Inconsistency in Aid Assessments for Voluntary Organisations providing Public Services”, EPPPL 2016, no. 1, pp. 31-38.

${ }^{70}$ P. Ferk, op. cit., fn. 18 , pp. 350-356.

${ }^{71}$ Green Paper on services of general interest (2003), pp. 14-15.

72 So also C. Wehlander, op. cit., fn. 63, p. 28. 
use this possibility if it brings no added value ${ }^{73}$. However, one can also agree with the authors, e.g. Erika Szyszczak and Ulla Neergaard, maintaining that it seems slightly ironic that the Commission decided not to use this option and that it remains loyal to the "soft" approach even after the legislative powers for the adoption of the long-awaited framework regulation of Article 14 TFEU have been provided ${ }^{74}$.

In this respect, we must recall, as noted by Sauter, that the EU's ticket to influence over public services is in governance and not spending power as the EU is not so much funding public services, as regulating their provision ${ }^{75}$.

Hence, to stay on the safe side, to still allow the concept of SGEIs to remain relatively open, and to provide some legal certainty to the matter, it seems necessary to transcend the casuistic approach and endeavours to draw an a priori list of all SGEIs/NESGIs. The current status which requires proficient knowledge of the existing legal framework and the CJEU case law on public services in order to properly define specific public services to be provided by e.g. a small municipality in one of the Member States without being highly likely to commit a "manifest error", is unsustainable in the long term. Therefore, I believe elements which fill the basic notions should be analytically clear at least to a stage of identifying certain common criteria/elements to be inherent to this notion. Here, I follow Damjan Kukovec's consideration that the "starting point of legal and economic analysis should be the complex hierarchical structure of production of goods, services, knowledge, authority, and prestige in global society that gives analytic clarity about its construction"76.

\section{CONCLUSION}

According to Duguit, from the very beginning, the ruled recognised they can impose some obligations on the rulers, while the execution of these obligations is simultaneously the excuse and consequence of their rising power. This should represent the essence of the public service. If, a contrario, a State at a certain stage is no longer able to (effectively) provide public services or even services in public interest in the broadest sense, what is then the argument that makes it a State?

73 See Communication from the Commission, A single market for 21st century Europe, $\mathrm{COM}(2007) 725$ final, p. 9; Communication from the Commission, A single market for 21st century Europe, $\operatorname{COM}(2007) 724$ final, pp. 10-11.

${ }^{74}$ See also E. Szyszczak, op. cit., fn. 11, pp. 5-7. For additional information see U. Neergaard, "The Commission's Soft Law in the Area of Services of General Economic Interest", [in:] E. Szyszczak et al., (eds.), Developments in Services of General Interest, The Hague 2011, pp. 44-50.

75 W. Sauter, op. cit., fn. 67, p. 108.

76 D. Kukovec, "Economic Law, Inequality and Hidden Hierarchies on the EU Internal Market", Michigan Journal of International Law 2016; EUI Department of Law Research Paper no. 7, Vol. 38, no. 1, p. 4; Available from: <http://ssrn.com/abstract=2748559> (14 August 2016); D. Kukovec, "Law and the Periphery", European Law Journal 21, no. 3, pp. 406-428. 
Considering the fact that the provision of public services is falling behind due to a number of correlated reasons identified in this paper, a reform in this area is practically inevitable.

However, since these reasons and the EU development are closely intertwined, the reform should commence by identifying, analysing, and defining the meaning of public services as one of the key enablers of fundamental rights in the EU. Afterwards, we might come to a conclusion that public services could indeed be the new pillar of the legitimacy of the European integration. The second part, which includes the organisational/financial/legal provision of public services and the strategic development of suitable financial mechanisms, will then be a considerably simpler issue to address, especially since the appropriate mechanisms have already been developed and since the necessary know-how and experience already exist.

\title{
USŁUGI UŻYTECZNOŚCI PUBLICZNEJ JAKO PRAWA PODSTAWOWE OBYWATELI UNII EUROPEJSKIEJ W DOBIE KRYZYSU
}

\begin{abstract}
Streszczenie
Autorka analizuje problem z zakresu prawa Unii Europejskiej, który dotyczy przestrzegania praw podstawowych przysługujących obywatelom Unii Europejskiej w związku ze świadczeniem usług użyteczności publicznej. Obecnie, w dobie kryzysu, instytucje unijne są szczególnie zobowiązane, by w większym stopniu skupić swoją uwagę na prawach podstawowych oraz roli i znaczeniu systemu usług użyteczności dla ich poszanowania. Co więcej, usługi publiczne powinny być postrzegane jako jeden z filarów, na których opiera się integracja europejska, wzmacniając legitymizację władzy w UE, podobnie jak ma to miejsce w państwach członkowskich, zgodnie z teorią, że rządzący są tylko pracownikami usług publicznych.
\end{abstract}

